\title{
Land dataset uncertainty: effect on Romanian National Greenhouse Gas Inventory
}

\author{
V.N.B. Blujdea, Gh. Marin, M. Stoichițescu
}

Blujdea V.N.B., Marin Gh., Stoichițescu M., 2014. Land dataset uncertainty: effect on Romanian National Greenhouse Gas Inventory Ann. For. Res. 57(2): 299-317, 2014.

Abstract. The availability of long-term land datasets is fundamental to ensure consistent and accurate national greenhouse gas inventories for land use and land use changes. Estimation of Romania's $\mathrm{CO}_{2}$ removals and emissions over 1970-2010 was assessed comparatively by using $\mathrm{Na}$ tional Statistics (as reference dataset), Corine Land Cover data, as well as four additional datasets produced from the reference dataset and assuming some forest data changes according to other available partial datasets (NFI,LUCAS or expert judgment). A spreadsheet, implementing a model of UNFCCC national greenhouse gas inventory, allowed estimation of both net $\mathrm{CO}_{2}$ removals and emissions and gross $\mathrm{CO}_{2}$ fluxes from all carbon pools, for all land subcategories over 1970-2010. The model was run for each dataset. The reference dataset resulted in an average annual gross flux of $\mathrm{CO}_{2}$, twice as large as the corresponding annual net removals of $13 \mathrm{Tg}$ $\mathrm{CO}_{2}$, while annual estimates were more than double in post-1990 compared to pre-1990. Uncertainty of net annual $\mathrm{CO}_{2}$ removals by reference dataset was estimated around $31 \%$, slightly lower than for gross estimate, and just around $55 \%$ when based on CLC dataset. Overall, the contribution of 12 broad land sub-categories to $\mathrm{CO}_{2}$ inventory was similar in the national net and gross estimates, for both pre- and post-1990 periods. Land under conversion represented $9 \%$ of the country's area in pre- and only $2 \%$ in post-1990, corresponding to an annual average of $28 \%$ of gross and $6 \%$ of net annual $\mathrm{CO}_{2}$ estimates. Among the choices of datasets tested, the reference dataset provided the most conservative estimates of the $\mathrm{CO}_{2}$ inventory. Other datasets generally overestimated annual LULUCF sink and its main contributor forestland, as well as the emissions or removals from land conversion. Compared to pre-1990, when annual sink was rather low, land abandonment and moderating management in the post-1990 period has led to an increase of $\mathrm{C}$ stock in all pools, showing the relevance of political changes on land's $\mathrm{CO}_{2}$ emissions/removals. Inconsistency within available land datasets impairs more accurate estimation of national GHG inventory. The development of an improved land use assessment system around $\mathrm{Na}$ tional Forest Inventory is therefore suggested as a solution to implement consistent land definitions and to accurately estimate their areas in time. Keywords $\mathrm{CO}_{2}$, datasets, national inventory, land category, pre/post 1990 period. 
Authors. Viorel Nelu Belmondo Blujdea - Forest Research and Management Institute, Eroilor Av. 114, Voluntari, Ilfov, Romania; Gheorghe Marin, Mihai Stoichițescu - National Forest Inventory, Voluntari, Ilfov, Eroilor Av. 114, Romania.

Manuscript received January 22, 2014; revised October 29, 2014; accepted November 20, 2014; online first November 27, 2014.

\section{Introduction}

While land use activities have significant economic contribution at the global level, they also matter because of their high contribution to greenhouse gas (GHG) emissions and $\mathrm{CO}_{2}$ removals, mainly from land use change, which is the second-largest anthropogenic source of $\mathrm{CO}_{2}$ (e.g. Houghton et Hackler 2001, Foley et al. 2005, Le Quéré et al. 2011). Estimating emissions and reporting a national GHG inventory constitutes an ongoing obligation for 44 developed country-parties listed in the Annex I of the United Nations Framework Convention for Climate Change (UNFCCC). National GHG inventory for land use, land use change and forestry (LULUCF) is a relatively recent policy requirement, which has critical links to economic development at both the national and regional scale: concerning food and energy security, climate change adaptation and low carbon economy (e.g. Goulet et Morlat 2011, Van der Krabben \& Jacobs. 2013, Ostle et al. 2009, Rounsevell \& Reay 2009, USDA 2008, Exnerova \& Cienciala 2009, Brown et al. 2012, Lewis 2010). Thus, national GHG inventory can be a powerful tool to support policy and decision making regarding the control of anthropogenic emissions on land at macroscale, in complement to subject oriented life cycle analysis considered as more adequate for understanding the atmospheric impact (Ostle et al. 2009). On the other hand, although GHG estimation and reporting are standardized via IPCC guidelines (e.g. IPCC 2003), it is largely acknowledged that a national inventory may not truly account for direct human effects or accurately reflect where and when emissions occur (Stinson et al. 2011).

Reporting national GHG inventories needs to follow key principles: transparency, consistency, comparability, completeness, accuracy (UNFCCC 2011). Data type and quality contribute to reach all of them, while ignoring related uncertainty results in unreliable inventory estimates. The accepted rule is that the best available data should always be used for a land-related commitment, and attempts should be made to quantify uncertainties that arise from the dataset choice (Dendoncker 2008, IPCC 2003). Furthermore, in order to comply with their emissions reduction targets, developed countries committed to account GHG emissions and $\mathrm{CO}_{2}$ removals from eligible activities of land use, under specific common accounting rules GHG. In fact, reporting requirements differ for the inventory (which needs, as a minimum, historical statistical data on land categories) and compliance with emissions reduction targets (e.g. spatial identification and tracking in time) which are obviously not met by ordinary land statistics (UNFCCC 2005).

For Eastern European countries, while more is known on local or national driving factors causing land use change, i.e. the collapse of the socialist regime (Ioras \& Abrudan 2006, Hostert et al. 2011), less is known about the status and trends of sinks and sources and their associated climatic impact, especially at regional level (Kuemmerle et al. 2011). Furthermore, the capacity of these countries to accurately estimate and report national GHG inventories to UNFCCC has been under scrutiny and, as consequence, their eligibility for emissions reduction transaction under the Kyoto Protocol was recently temporarily suspended (i.e. Bul- 
garia, Croatia, Lithuania, Romania, Slovakia and Ukraine). Such estimating, reporting and accounting issues have occurred despite their good forestry databases, while it is generally recognized that the uncertainty due to incomplete coverage of forest-related estimates occurs even in countries with the most sophisticated forest inventories - largely developed nations in Europe and North America (Reich, 2011). Another common major problem is that reporting GHG inventory for non-forest lands is less documented compared to forest-related lands, which undermines the reliability of the overall LULUCF inventory.

Romania, the third largest country in Eastern Europe, reports a national GHG inventory and has also committed under Kyoto Protocol to account GHG emissions and $\mathrm{CO}_{2}$ removals from forest management and revegetation activities, in addition to mandatory ones, the afforestation/reforestation and deforestation. Current official estimation of the Romanian GHG inventory relies on land statistics, which is the only official data source available historically. Nevertheless, over the last two decades several integral or sectorial land datasets have been developed and the obvious question rises on which one to use, or, how to combine information to meet the inventory and emission reduction compliance reporting requirements, and reduce estimates uncertainties.

Thus, the purpose of this work was to quantitatively analyze how the LULUCF's national inventory of $\mathrm{CO}_{2}$ removals and emissions estimates are affected when using various land datasets as compared to the reference one provided by the official national statistics. We also try to assess the uncertainty introduced by land data into GHG inventory and which might be the data needs for consistent and complete estimation and reporting of the $\mathrm{CO}_{2}$ emissions and removals from land. Implicitly, the GHG effect of land use policy in pre- and post-1990 and contribution of land conversions to national GHG inventory over 1970-2010 are assessed.

\section{Material and methods}

This assessment consisted in the estimation of the Romania's national inventory of anthropogenic $\mathrm{CO}_{2}$ emissions and removals from carbon pools associated to LULUCF over 1970-2010 comparatively for several land use datasets. Overall, the estimation follows UNFCCC national GHG inventory 'gain-loss' method, which consists in multiplication of area of certain land category with the corresponding annual value of $\mathrm{C}$ stock change factor for that land, assuming consistent land representation criteria are met by both data required. A key assumption in this analysis was that any nationally available data would have an equal chance to be used for the estimation of the national GHG inventory. Currently official land data are described in Table 1. The datasets considered differ with regard to their purpose, underlying definitions (e.g. use or cover) or measurement methods used.

Further on, we derived six datasets for the $\mathrm{CO}_{2}$ inventory estimates comparison: two independent datasets (i.e. $\mathrm{D}_{\text {reference, }}, \mathrm{D}_{\mathrm{CLC}}$ ) as provided by original standing alone sources mentioned in Table 1 and four variations of the reference dataset (i.e. $\mathrm{MD}_{\text {non-LUC }}, \mathrm{MD}_{\text {hayfield }}$, $\mathrm{MD}_{\text {arable }}, \mathrm{MD}_{\text {combined }}$ ), as described in Table 2. Variations mainly took into account the results of unique, by now, estimates of newest land assessment instruments (Eurostat's Land Use/ Cover Area frame Statistical Survey; LUCAS, 2012) and Romania's National Forest Inventory; NFI 2010) and expert guess. For realistic estimates, annual area of conversions to/from national forest fund was applied to all datasets, except for CLC (for which we only verified if it reports larger areas of conversions than by Forestry Operational Report).

Each of the six datasets was then considered as input in a Land Use and change Matrix (LUM), which is a MS Excel spreadsheet underlying $\mathrm{CO}_{2}$ inventory estimation, i.e. LUM was run for each of six datasets, and results were compared. LUM implemented the key 
Table 1 Land use and cover data available for Romania

\begin{tabular}{|c|c|c|c|c|c|}
\hline $\begin{array}{l}\text { Dataset and } \\
\text { temporal } \\
\text { availability }\end{array}$ & $\begin{array}{l}\text { Main feature of } \\
\text { dataset }\end{array}$ & Forest \& forestland & Cropland & Grassland & $\begin{array}{l}\text { Other land } \\
\text { categories }\end{array}$ \\
\hline $\begin{array}{l}\text { National } \\
\text { Institute of } \\
\text { Statistics } \\
\text { (annual official } \\
\text { report since } \\
1970 \text { ) }\end{array}$ & $\begin{array}{l}\text { Land use data } \\
\text { from land } \\
\text { registry or } \\
\text { cadastral data } \\
\text { (heterogeneous } \\
\text { across country } \\
\text { territory, } \\
\text { occasionally geo- } \\
\text { referenced and } \\
\text { updated). Annual } \\
\text { report with full } \\
\text { country coverage }\end{array}$ & $\begin{array}{l}\text { Annual area of 5.96- } \\
6.33 \text { Mha (national } \\
\text { forest fund) \& } 0.41 \text { - } \\
0.45 \text { Mha (forest } \\
\text { vegetation outside } \\
\text { the national forest } \\
\text { fund or woodland) }\end{array}$ & $\begin{array}{l}\text { Annual area } \\
\text { ranging } \\
\text { between 9.33- } \\
9.92 \text { Mha for } \\
\text { arable and } \\
0.37-0.70 \text { Mha } \\
\text { for permanent } \\
\text { woody crops }\end{array}$ & $\begin{array}{l}\text { Annual area } \\
\text { between } 2.70- \\
3.42 \text { Mha for } \\
\text { pasture and } \\
1.36-1.71 \mathrm{Mha} \\
\text { for hayfields }\end{array}$ & $\begin{array}{l}\text { Water/ponds } \\
\text { cover between } \\
0.71-0.91 \text { Mha. } \\
\text { Artificial areas } \\
\text { (e.g. urban, } \\
\text { infrastructure) } \\
\text { cover between } \\
\text { 1.0-1.61 Mha }\end{array}$ \\
\hline $\begin{array}{l}\text { Corine } \\
\text { Land Cover } \\
\text { (European } \\
\text { Environmental } \\
\text { Agency's } \\
\text { 'coordination } \\
\text { of information } \\
\text { on the } \\
\text { environment') }\end{array}$ & $\begin{array}{l}\text { Land cover data } \\
\text { and maps for } \\
1990,2000 \text { and } \\
\text { 2006. Spatially } \\
\text { explicit and } \\
\text { country coverage }\end{array}$ & $\begin{array}{l}\text { Total forest and } \\
\text { semi-natural areas } \\
(8.021 / 8.019 / 8.013)\end{array}$ & $\begin{array}{l}\text { Annual area of } \\
8.96 / 8.95 / 9.04 \\
\text { Mha, including } \\
0.8 / 0.78 / 0.74 \\
\text { Mha of } \\
\text { orchards and } \\
\text { vineyards }\end{array}$ & $\begin{array}{l}\text { Annul area of } \\
4.55 / 4.56 / 4.52 \\
\text { Mha, out } \\
\text { of which } \\
2.02 / 2.03 / 1.94 \\
\text { Mha of } \\
\text { hayfield }\end{array}$ & $\begin{array}{l}\text { Water/ponds } \\
\text { cover between } \\
0.71 / 0.71 / 0.74 \\
\text { Mha. Artificial } \\
\text { areas cover } \\
1.45 / 1.46 / 1.47 \\
\text { Mha }\end{array}$ \\
\hline $\begin{array}{l}\text { Forestry } \\
\text { operational } \\
\text { reports (annual } \\
\text { forest Authority } \\
\text { reports) }\end{array}$ & $\begin{array}{l}\text { Annual area } \\
\text { of conversions } \\
\text { to/ from forest } \\
\text { within national } \\
\text { territory is } \\
\text { measured on the } \\
\text { ground, mapped } \\
\text { (not geo- } \\
\text { referenced) and } \\
\text { national statistics } \\
\text { adjusted }\end{array}$ & $\begin{array}{l}\text { Annual average } \\
\text { afforestation areas } \\
12 / 1.28 \text { kha and } \\
\text { revegetation of } \\
4.3 / 0.5 \text { kha in pre/ } \\
\text { post-1990 }\end{array}$ & $\mathrm{ND} / \mathrm{NI}$ & $\mathrm{ND} / \mathrm{NI}$ & $\begin{array}{l}\text { Annual data on } \\
\text { deforestation of } \\
14.5 / 0.5 \text { kha in } \\
\text { pre/post-1990 }\end{array}$ \\
\hline
\end{tabular}

Note. 1 Mha $=1$ million hectares. Parenthesis shows min and max of area over 1970-2010, whenever available. ND/NI -data not available/no information.

rule that any land within national territory is classified under a unique land use category (i.e. area of activity data) which has associated a specific annual $\mathrm{C}$-stock change in each carbon pool (i.e. $\mathrm{CO}_{2}$ emissions or removals factor), following UNFCCC reporting requirements (IPCC, 2003; IPCC, 2006). Similar models are used by other countries to report national GHG inventories (e.g. in the USA, see Woodbury et al. 2007, or UK, see UK 2012). Inputs in LUM were disaggregated as available in the original dataset, but finally aggregated according to six broad land categories defined by 302
Good Practice Guidelines for Land Use, Land Use Change and Forestry (IPCC 2003): FLforestland; CL-cropland; GL-grassland; WLwetland; SL-settlements and OL-other land. According to possible change of land use from one year to next, each category is composed from two subcategories: "remaining" and "in conversion to". For the year when a conversion initiates, the spreadsheet subtracts the area starting the conversion from the 'remaining' of the original land category and moves it under "conversion to" of the target land category where it is maintained for 20 years and 
Table 2 Land area datasets input and description, as standing alone datasets (D) and reference dataset variations (MD). Relative values (\%) and \pm signs denote percentage larger or smaller inputs compared to reference dataset values.

\begin{tabular}{|c|c|c|}
\hline Datasets & $\begin{array}{l}\text { Description/range for input } \\
\text { data }\end{array}$ & Justifications/assumption \\
\hline $\mathrm{D}_{\text {reference }}$ & Reference dataset & $\begin{array}{l}\text { Official land data from National Institute of Statistics (www. } \\
\text { insse.ro) and area of conversions to/from national forest fund. } \\
\text { Currently used in Romania's submission to UNFCCC (U } \\
\text { Government of Romania, 2011) }\end{array}$ \\
\hline $\mathrm{D}_{\mathrm{CLC}}$ & $\begin{array}{l}\text { Inputs size compared to } \\
\text { reference (roughly): }-13 \% \\
\text { arable, }-10 \% \text { pasture, }+20 \% \\
\text { hayfields, }+50 \% \text { vineyards and } \\
\text { orchards, }+137 \% \text { woodland } \\
\text { and }+12 \% \text { forestland }\end{array}$ & $\begin{array}{l}\text { Net areas for years } 1990,2000 \text { and } 2006 \text { from CLC. Areas } \\
\text { in conversions are interpolated in-between and extrapolated } \\
\text { backward to } 1970 \text { with an annual rate as for 1990-2000 and } \\
\text { upward from } 2006 \text { with a rate as of } 2000-2006\end{array}$ \\
\hline $\mathrm{MD}_{\text {non-LUC }}$ & No land use change since 1970 & $\begin{array}{l}\text { Constant land use as reported by reference dataset for the year } \\
1970 \text { applied throughout the time series } 1970-2010\end{array}$ \\
\hline $\mathrm{MD}_{\text {hayfield }}$ & No woodland & $\begin{array}{l}\text { Woodland area reported by reference dataset was assumed } \\
\text { as hayfields. Reason is that there is no strict implementation } \\
\text { of forest definition in current official reporting process by } \\
\text { relevant owners, and no enforceable legal provision for their } \\
\text { administration as forests, thus under risk of being maintained } \\
\text { as forest for short period of time before reconversion to } \\
\text { hayfields. As well, there is no information on tree vegetation } \\
\text { characteristics. }\end{array}$ \\
\hline $\mathrm{MD}_{\text {arable }}$ & Less arable land & $\begin{array}{l}\text { Assess the CO2 effect of the change of largest land category. } \\
10 \% \text { less arable land applied to reference data for entire time } \\
\text { series, in favor of pasture (because of overstating cultivated } \\
\text { area by reporting marginal arable land as productive land in } \\
\text { pre- } 1990 \text { and abandonment in post-1990) }\end{array}$ \\
\hline $\mathrm{MD}_{\text {combined }}$ & $\begin{array}{l}\text { Reference data in } 1970 ; \\
\text { progressive increase to }+100 \% \\
\text { woodland on hayfield in } 2010 \\
\text { and decrease to }-10 \% \text { arable } \\
\text { converted to pasture }\end{array}$ & $\begin{array}{l}\text { Likely most realistic scenario based on expert judgment } \\
\text { applied to reference data as supported by NFI and LUCAS } \\
\text { results (taking into account abandonment of marginal } \\
\text { agricultural lands of various uses and progressive expansion of } \\
\text { forest vegetation coupled with enforcement of their long term } \\
\text { management) }\end{array}$ \\
\hline
\end{tabular}

only afterwards it is added to the "remaining" of that new category. This approach follows GPG for LULUCF (IPCC, 2003) ensuring that "actual" rather than "potential" $\mathrm{CO}_{2}$ emissions and removals are estimated for slow changing pools (i.e. soil organic matter). Inputs into the LUM were "net area at the end of year" for each land subcategory or division as nationally aggregated areas reported by dataset. LUM assumes that the net area of land 'remaining' in the same category is the minimum between current and previous year, whichever was the smallest, while the difference was considered as starting or ending some conversion. Further- more, because faith of areas starting conversion was not known, conversions to in LUM were modulated by a "conversions allocation factor", i.e. the most probable ratio of transfers $(\%)$ from one category to all others in a year, applied to all datasets. These factors were derived based on documented data like forest authority statistics, i.e. $80 \%$ of annual conversions from forest occurred to settlements (i.e. road infrastructure) and $20 \%$ to other land (e.g. because of active riverbank erosion along more than $1000 \mathrm{~km}$ of Danube). For non-forest conversions, the main target categories and allocation factors were set according to expert 
judgment: orchards converted to arable (10\%), pasture $(60 \%)$ and woodlands $(25 \%)$; arable to wetlands $(23 \%)$ and grassland $(60 \%$ to either "pasture" or "hayfield"); grasslands to arable (40\%), woodland (20\%) and wetlands (20\%); settlements (i.e. mining and industrial dumps) to forestland $(10 \%)$ and other land $(80 \%)$. For improbable conversions factors values were set to $1 \%$, thus not totally excluded (adding $100 \%$ for each conversion). Allocation factors were assumed constant for the entire time series 1970-2010. Rules incorporated within LUM have been designed to minimize transition to other land (non classified under other well defined categories, as barren, rocks, etc) and to minimize its buffering role (e.g. share of the area under conversion to/from other land was an adequate indicator of LUM functioning, i.e. negligible areas of some $0.2 \%$ of total country area proves its reasonable allocation ability). LUM robustness was also ensured by checking that sum of areas of all land categories at country level to be constant.

The spreadsheet model derived both 'net' annual $\mathrm{CO}_{2}$ removals or emissions and 'gross' fluxes of $\mathrm{CO}_{2}$ as absolute annual amounts for each land category and pool. To meaningfully compare the effect of the six land datasets, identical values of $\mathrm{C}$-stock change factors were used for inventory estimates (Table 1). Ecology and management specificities implemented on each land category were accounted for in the spreadsheet by further disaggregation (i.e. on forest type, woody/non-woody crops), down to levels for which $\mathrm{C}$ stock change values were available (following the approach of the national GHG inventory currently reported to UNFCCC; Government of Romania, 2012). In order to easily deal with inter-annual variability and capture pre- and post-1990 land management changes, net and gross estimates were reported as the sum over inventory intervals (i.e. 1970-2010 or broken down for preand post-1990).

For estimating the contribution of land datasets uncertainty to the overall uncertainty of the $\mathrm{CO}_{2}$ emissions and removals, a Monte Carlo simulation (RISK 6, Palisade Corporation, USA) was applied to the inputs for year 2010 within the LUM spreadsheet, following IPCC Tier 2 (IPCC, 2000; IPCC, 2003). An uncertain input was defined as the mean value and its relative standard deviation of the mean (see Table 1). Where data was available, standard error of the mean was used (e.g. C stock change in litter or biomass on lands in conversion to forests), otherwise a probability range of the mean as defined by the reference or based on expert guess (assuming mean is normally distributed). Analysis focused on a comparison of uncertainty of $\mathrm{CO}_{2}$ estimates given by two complete country coverage datasets (i.e. reference and CLC), cumulated with the uncertainty of the conversions allocation factors. Because of lacking of the variance of the area estimates of CLC, we assumed an uncertainty of $20 \%$ of the national total areas for any land category, as a compromise value knowing its underlying broad land classification based on remote sensing procedures of old datasets or mid-resolution imagery (Grassi et. al., 2008; Caetano et al., 2009) and good reported nominal accuracy of CLC products of $85 \%$ (Büttner et. al, 2002; EEA, 2006). Secondly, expert guess uncertainty of annual 'conversion allocation factors' was attached to non-forest conversions $( \pm 20 \%$ for from/to cropland, grassland, wetlands and $\pm 50 \%$ from/ to woodlands) and $5 \%$ from/to conversions of orchards, vineyards and settlements (subject to cadastre type measurements and updating frequency of databases). Simulations resulted in the estimation of relative uncertainty of $\mathrm{CO}_{2}$ emissions and removals estimates for individual land categories and inventory aggregated estimates, further complemented by a sensitivity assessment toward ranking of the inputs based on changes induced in the output (also performed by RISK6). 
Table 3 Annual C stock change values and uncertainty associated to reference dataset. Positive value indicate carbon gains in the pool, negative value indicate a carbon loss. Carbon (C) pools which were not shown in table were assumed as not changing in time at the national scale (e.g. soil organic matter in mineral soils on forestland, following Tier 1 assumption of IPCC GPG for LULUCF (2003). Values of $\mathrm{C}$ stock change in mineral soils may be overestimated for all conversions, but there is no better data available at this time

\begin{tabular}{|c|c|c|c|}
\hline $\begin{array}{l}\text { C stock /removals } \\
\text { or emissions source } \\
\text { category (unit) }\end{array}$ & $\begin{array}{l}\text { Annual C stock } \\
\text { change factor values/ } \\
\text { range }(\mathrm{t} C / \mathrm{yr} / \mathrm{ha})\end{array}$ & $\begin{array}{l}\text { Relative } \\
\text { uncertainty } \\
\text { / estimate (as } \pm 2 \\
\text { stdev of mean, } \\
\% \text { ) }\end{array}$ & $\begin{array}{l}\text { References for data and } \\
\text { uncertainty source or assumptions }\end{array}$ \\
\hline \multicolumn{4}{|c|}{ Forest Land remaining Forest Land } \\
\hline $\begin{array}{l}\text { Land area of national } \\
\text { forest fund/ woodlands }\end{array}$ & - & $\pm 5 / \pm 20$ & $\begin{array}{l}\text { Reference dataset as from forest } \\
\text { cadastre/ agricultural cadastre \& cadastre } \\
\text { specifications/expert guess }\end{array}$ \\
\hline 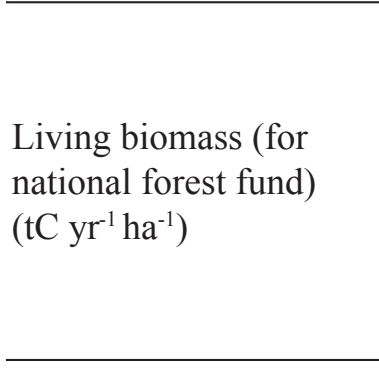 & $\begin{array}{l}\text { Average annual } \\
\text { increment between } \\
1.58-2.10, \text { and } \\
\text { decrease of } 0.24 \\
-0.38\end{array}$ & \pm 20 & $\begin{array}{l}\text { National scale aggregated values of annual } \\
\text { increment on species and groups of } \\
\text { species, according to the "Inventarul } \\
\text { Fondului Forestier National al Romaniei" } \\
\text { published in } 1985 \text { by the Ministry of } \\
\text { Silviculture of Romania (Government of } \\
\text { Romania 2014), official annual harvest } \\
\text { statistics and Giurgiu et al. (2004) }\end{array}$ \\
\hline $\begin{array}{l}\text { Living biomass (for } \\
\text { woodlands) }\left(\mathrm{tC} \mathrm{yr}^{-1} \mathrm{ha}^{-1}\right)\end{array}$ & $\begin{array}{l}\text { Average annual } \\
\text { increment of } 1.8 \\
\text { and decrease of } 0.3\end{array}$ & \pm 50 & $\begin{array}{l}\text { National scale average aggregated values } \\
\text { of annual increment according Synthesis } \\
\text { of sylvo-pastoral plans published in } 1990 \\
\text { by the Ministry of Silviculture of Romania } \\
\text { (Government of Romania 2014), and } \\
\text { annual harvest statistics and expert guess }\end{array}$ \\
\hline \multicolumn{4}{|c|}{ Land converted to Forest Land } \\
\hline $\begin{array}{l}\text { Land area of } \\
\text { conversions to national } \\
\text { forest fund/woodlands }\end{array}$ & - & $\pm 5 / \pm 20$ & $\begin{array}{l}\text { Cadastral type data by forestry statistics } \\
\text { and cadastre specifications/expert guess }\end{array}$ \\
\hline $\begin{array}{l}\text { Living biomass } \\
\left(\mathrm{tC} \mathrm{yr}^{-1} \mathrm{ha}^{-1}\right)\end{array}$ & $0.16 \div 2.61$ & \pm 10 & $\begin{array}{l}\text { Age-dependent growth of biomass from } \\
\text { Romania's joint Implementation project of } \\
\text { Afforestation (Government of Romania, } \\
\text { 2014) and uncertainty of project estimate } \\
\text { as standard }\end{array}$ \\
\hline 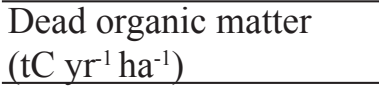 & $0.15 \div 0.32$ & \pm 25 & As above \\
\hline 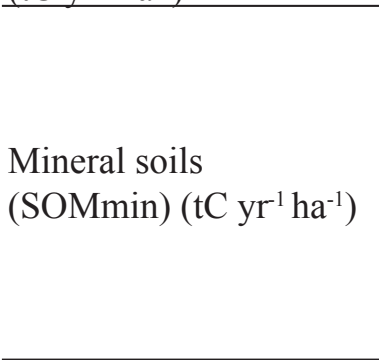 & $\begin{array}{l}+1.85 \text { from } \mathrm{CL} ; \\
+1.75 \text { from } \mathrm{GL}, \mathrm{WL} ; \\
+2.65 \text { from } \mathrm{SL} ; \\
+2.2 \text { from } \mathrm{OL}\end{array}$ & \pm 75 & $\begin{array}{l}\text { Difference between the national scale } \\
\text { average values of the C stocks associated } \\
\text { to each land use from "Monitoring of } \\
\text { soil quality in Romania" implemented } \\
\text { by National Research and Development } \\
\text { Institute for Soil Science, Agrochemistry } \\
\text { and Environment (Government of } \\
\text { Romania 2014) }\end{array}$ \\
\hline
\end{tabular}


Table 3 (continuation)

\begin{tabular}{|c|c|c|c|}
\hline $\begin{array}{l}\text { C stock /removals } \\
\text { or emissions source } \\
\text { category (unit) }\end{array}$ & $\begin{array}{l}\text { Annual C stock } \\
\text { change factor } \\
\text { values/range (tC/ } \\
\mathrm{yr} / \mathrm{ha})\end{array}$ & $\begin{array}{l}\text { Relative } \\
\text { uncertainty } \\
\text { estimate (as } \pm 2 \\
\text { stdev of mean, } \\
\% \text { ) }\end{array}$ & $\begin{array}{l}\text { References for data and } \\
\text { uncertainty source or assumptions }\end{array}$ \\
\hline \multicolumn{4}{|c|}{ Forest Land converted to other lands } \\
\hline $\begin{array}{l}\text { Land area of } \\
\text { conversions from } \\
\text { national forest fund/ } \\
\text { woodlands }\end{array}$ & & $\pm 5 / \pm 20$ & $\begin{array}{l}\text { Cadastral type data by forestry statistics } \\
\text { and cadastre specifications/expert guess }\end{array}$ \\
\hline Living biomass $\left(\mathrm{tC} \mathrm{ha}^{-1}\right)$ & -66.88 & \pm 10 & $\begin{array}{l}\text { Average standing C stock for national } \\
\text { forest fund estimated by Forest Inventory } \\
\text { (Government of Romania 2014) }\end{array}$ \\
\hline $\begin{array}{l}\text { Dead organic matter } \\
\left(\mathrm{tC} \mathrm{ha}^{-1}\right)\end{array}$ & $\begin{array}{l}-7.42 \text { for litter pool; } \\
-0.75 \text { for dead wood } \\
\text { pool }\end{array}$ & \pm 10 & $\begin{array}{l}\text { National average C stock in litter pool } \\
\text { from ICP Forest database (Government of } \\
\text { Romania 2014), and lying dead wood pool } \\
\text { from NFI (IFN 2014) }\end{array}$ \\
\hline 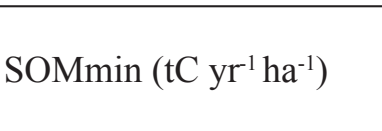 & $\begin{array}{l}-1.85 \text { to } \mathrm{CL} ;-1.75 \\
\text { to } \mathrm{GL}, \mathrm{WL} ;-2.65 \text { to } \\
\mathrm{SL} ;-2.2 \text { to } \mathrm{OL}\end{array}$ & \pm 50 & As for land converted to forests \\
\hline \multicolumn{4}{|l|}{ Cropland } \\
\hline $\begin{array}{l}\text { Land area and areas in } \\
\text { conversions to cropland }\end{array}$ & & $\pm 5 / \pm 50$ & Cadastral data and expert guess \\
\hline 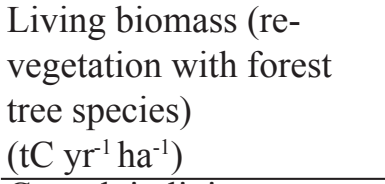 & $0.16-2.61$ & \pm 10 & As for land converted to forests \\
\hline $\begin{array}{l}\mathrm{C} \text { stock in living } \\
\text { biomass (non-forest } \\
\text { woody vegetation) } \\
(\mathrm{tC} / \mathrm{ha})\end{array}$ & 63 & \pm 75 & From IPCC (2003) \\
\hline $\begin{array}{l}\text { Living biomass (net } \\
\text { annual change) } \\
\left(\mathrm{tC} \mathrm{yr}^{-1} \mathrm{ha}^{-1}\right)\end{array}$ & 2.1 & \pm 50 & From IPCC (2003) \\
\hline $\begin{array}{l}\text { SOMmin under arable } \\
\text { land }\left(\mathrm{tC} \mathrm{yr}^{-1} \mathrm{ha}^{-1}\right)\end{array}$ & -0.05 & \pm 50 & $\begin{array}{l}\text { Simple average of net C stock changes } \\
\text { reported by all } 27 \text { member states of the } \\
\text { European Union in their national GHG } \\
\text { inventories submitted to UNFCCC in } 2012 \\
\text { (Mandl et al. 2012) }\end{array}$ \\
\hline $\begin{array}{l}\text { SOMmin under } \\
\text { permanent croplands } \\
(\mathrm{e} . \mathrm{g} . \text { orchards) } \\
\left(\mathrm{tC} \mathrm{yr}^{-1} \mathrm{ha}^{-1}\right)\end{array}$ & 0.01 & \pm 50 & As above \\
\hline 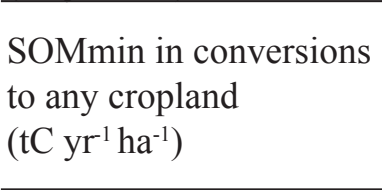 & 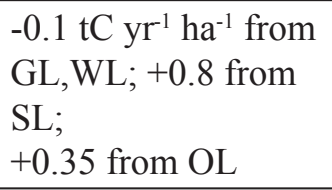 & \pm 50 & As for land converted to forests \\
\hline \multicolumn{4}{|l|}{ Grassland } \\
\hline $\begin{array}{l}\text { Land area and areas in } \\
\text { conversions to grassland }\end{array}$ & & $\pm 20 / \pm 50$ & Cadastral data and expert guess \\
\hline
\end{tabular}


Table 3 (continuation)

\begin{tabular}{|c|c|c|c|}
\hline $\begin{array}{l}\text { C stock /removals or } \\
\text { emissions source category } \\
\text { (unit) }\end{array}$ & $\begin{array}{l}\text { Annual } \mathrm{C} \text { stock change factor } \\
\text { values/range }(\mathrm{tC} / \mathrm{yr} / \mathrm{ha})\end{array}$ & $\begin{array}{l}\text { Relative } \\
\text { uncertainty } \\
\text { estimate (as } \pm 2 \\
\text { stdev of mean, } \\
\% \text { ) }\end{array}$ & $\begin{array}{l}\text { References for data and } \\
\text { uncertainty source or } \\
\text { assumptions }\end{array}$ \\
\hline $\begin{array}{l}\mathrm{C} \text { stock in living biomass } \\
\left(\mathrm{tC} \mathrm{ha}^{-1}\right)\end{array}$ & 0.85 & \pm 75 & From IPCC (2003) \\
\hline $\begin{array}{l}\text { Living biomass (net annual } \\
\text { change) } \\
\left(\mathrm{tC} \mathrm{yr}^{-1} \mathrm{ha}^{-1}\right)\end{array}$ & 0.01 & \pm 75 & $\begin{array}{l}\text { As for SOMmin under } \\
\text { Cropland }\end{array}$ \\
\hline 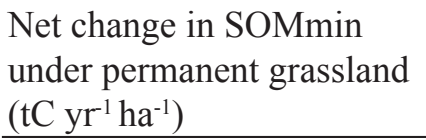 & 0.01 & \pm 50 & $\begin{array}{l}\text { As for SOMmin under } \\
\text { Cropland }\end{array}$ \\
\hline 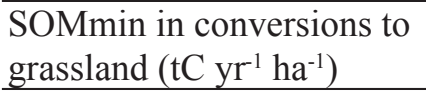 & $\begin{array}{l}+0.1 \text { from } \mathrm{CL} ; 0 \text { from } \mathrm{WL} ; \\
+0.9 \text { from } \mathrm{SL} ;-0.45 \text { from } \mathrm{OL}\end{array}$ & \pm 50 & $\begin{array}{l}\text { As for land converted to } \\
\text { Forestland }\end{array}$ \\
\hline \multicolumn{4}{|c|}{ Settlements } \\
\hline Land area & - & \pm 5 & $\begin{array}{l}\text { Cadastral data/expert } \\
\text { guess }\end{array}$ \\
\hline 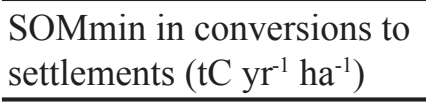 & $\begin{array}{l}-0.8 \text { from } \mathrm{CL} ;-0.9 \text { from } \mathrm{GL}, \mathrm{WL} ; \\
-0.45 \text { from } \mathrm{OL}\end{array}$ & \pm 50 & $\begin{array}{l}\text { As for land converted to } \\
\text { Forestland }\end{array}$ \\
\hline
\end{tabular}

\section{Results}

\section{Quantitative results from the 'reference' dataset}

Areas of land categories have experienced little changes from 1970 to 2010 . The largest cumulated increase of forestland and grassland areas by some $5 \%$ was balanced by a strong decrease of settlements and other land, by $24 \%$ and $34 \%$, respectively. Across time, other land category remained constant to some $0.2 \%$ of the total country area (i.e. less than $0.5 \mathrm{Mha}$ ). Overall, some $9 \%$ of the country area was involved in conversions in 1989 and only $2 \%$ in 2010 (first one capturing pre-1990 and the second post-1990 pictures, as long as the total area reported as "conversion to' represents the cumulated areas starting conversion over previous 20 years). Conversions from forestland and grassland, that hold the highest C-stock pools, decreased to roughly half during the post-1990 period, under lower economic pressure on land. Conver- sions from settlements also decreased after 1990, because of a lesser ecological restoration of the industrial and mining dumps, while the area of conversions to settlements decreased because of much reduced need of land for new industrial activities, not yet compensated by residential expansion in post-90.

Over 1970-2010, LULUCF was a sink amounting net $\mathrm{CO}_{2}$ removals of $538 \mathrm{Tg} \mathrm{CO} 2$ resulting from gross fluxes totaling $1,219 \mathrm{Tg}$ $\mathrm{CO}_{2}$. Meanwhile, both net and gross annual estimates varied $\pm 100 \%$ compared to the average for the 40 years span, i.e. an annual net removals of $13 \mathrm{Tg} \mathrm{CO}_{2}$ or gross flux of $30 \mathrm{TgCO}_{2}$. Annual average gross estimate was $25 \%$ larger in post-1990 compared to pre-1990, while net one increased some six times (Table 4).

Major land categories were consistently sinks while land conversions were either small sources or sinks. The highest contribution to GHG inventory was from forestland (removals from 'remaining' contributed some 53\% in gross or $118 \%$ in net estimate over entire 1970-2010), 'conversion to' forest 15\% 
Table 4 Annual average net $\mathrm{CO}_{2}$ emissions or removals on land subcategories for pre- and post- 1990 for reference scenario. $\boldsymbol{r}$ denotes land "remaining" in the same category and $\boldsymbol{c}$ denotes "converted to". By UNFCCC convention negative sign (-) shows CO2 removals from atmosphere, while positive one $(+)$ emissions to atmosphere

\begin{tabular}{llcc}
\hline Land category & $\begin{array}{l}\text { Pre-1990 } \\
\left(\mathrm{GgCO}_{2} \mathrm{yr}^{-1}\right)\end{array}$ & $\begin{array}{l}\text { Post-1990 } \\
\left(\mathrm{GgCO}_{2} \mathrm{yr}^{-1}\right)\end{array}$ & Change post-1990 to pre-1990 (\%) \\
\hline FL $r$ FL & -9417 & -21358 & 127 \\
Conversions from FL & 2383 & 777 & -68 \\
$\mathrm{cFL}$ & -3899 & -5262 & 35 \\
$\mathrm{CL} r \mathrm{CL}$ & 432 & 716 & 66 \\
$\mathrm{GL} r \mathrm{GL}$ & -300 & -321 & 7 \\
$\mathrm{cCL}$ & 741 & 142 & -81 \\
$\mathrm{cGL}$ & 937 & 217 & -77 \\
$c \mathrm{WL}$ & 230 & -29 & -113 \\
$c \mathrm{SL}$ & 6447 & 1590 & -75 \\
$c \mathrm{OL}$ & 1747 & 1661 & -5 \\
Total & -3083 & -22645 & 635 \\
\hline
\end{tabular}

in gross or $35 \%$ in net and 'conversions to settlements' (with $30 \%$ in gross or $13 \%$ in net LULUCF estimate). Although revegetated areas (e.g. tree plantations on arable land) are a small sink, cropland remaining cropland, which hosts them, was a small source because of emissions from changes in woody crops area (e.g. orchards, vineyards). On the other hand, emissions and removals from land conversions contributed $8 \%$ of total net removals, as driven by lands in conversion to forestland and settlements, being smaller in post- compared to pre-1990. Emissions associated to conversion from forest (i.e. deforestation) were larger in pre-1990, offsetting $77 \%$ of the annual net LULUCF sink (or $25 \%$ from forestland removals), compared to only $3 \%$ in post- 1990 (or $3 \%$ from forestland removals), associated to an absolute change of annually deforested area which dropped from some $15 \mathrm{kha}$ in pre-1990 to some $0.5 \mathrm{kha}$ in post-1990. Overall, halving conversions to forest in post-1990 and much less conversions for non-forest lands resulted in large increase in $\mathrm{CO}_{2}$ removals.

\section{Comparisons of net and gross $\mathrm{CO} 2$ fluxes by various land datasets}

The estimates for 1970-2010 derived by two standing alone datasets, reference and CLC (Figure 1) have the same general pattern, both also captured the effect of land use changes between pre- and post-1990 (e.g. peaks on all graphs) and wood harvesting level change in post- compared to pre-1990.

Compared to $\mathrm{D}_{\mathrm{CLC}}$ which smoothed the time series by annualization of land use changes, reference dataset strongly reflected the interannual variability (e.g. drop of areas of vineyards and orchards reported in 1977 and 1979). This way, reference dataset allowed more inclusive reporting of annual $\mathrm{CO}_{2}$ emissions and removals from LULUCF sector: $\mathrm{D}_{\text {CLC }}$ resulted in $-28 \%$ of the gross and $+19 \%$ of the net $\mathrm{CO}_{2}$ inventory estimates compared to reference. Assuming no change of the land categories areas over 1970-2010 ( $\mathrm{MD}_{\text {non-LuC }}$ ), resulted in -28\% of the gross and $+16 \%$ of the net $\mathrm{CO}_{2}$ estimates compared to reference.

Variations by partial modifications of the reference dataset resulted in negligible changes in gross and slight overestimation of total net LULUCF 


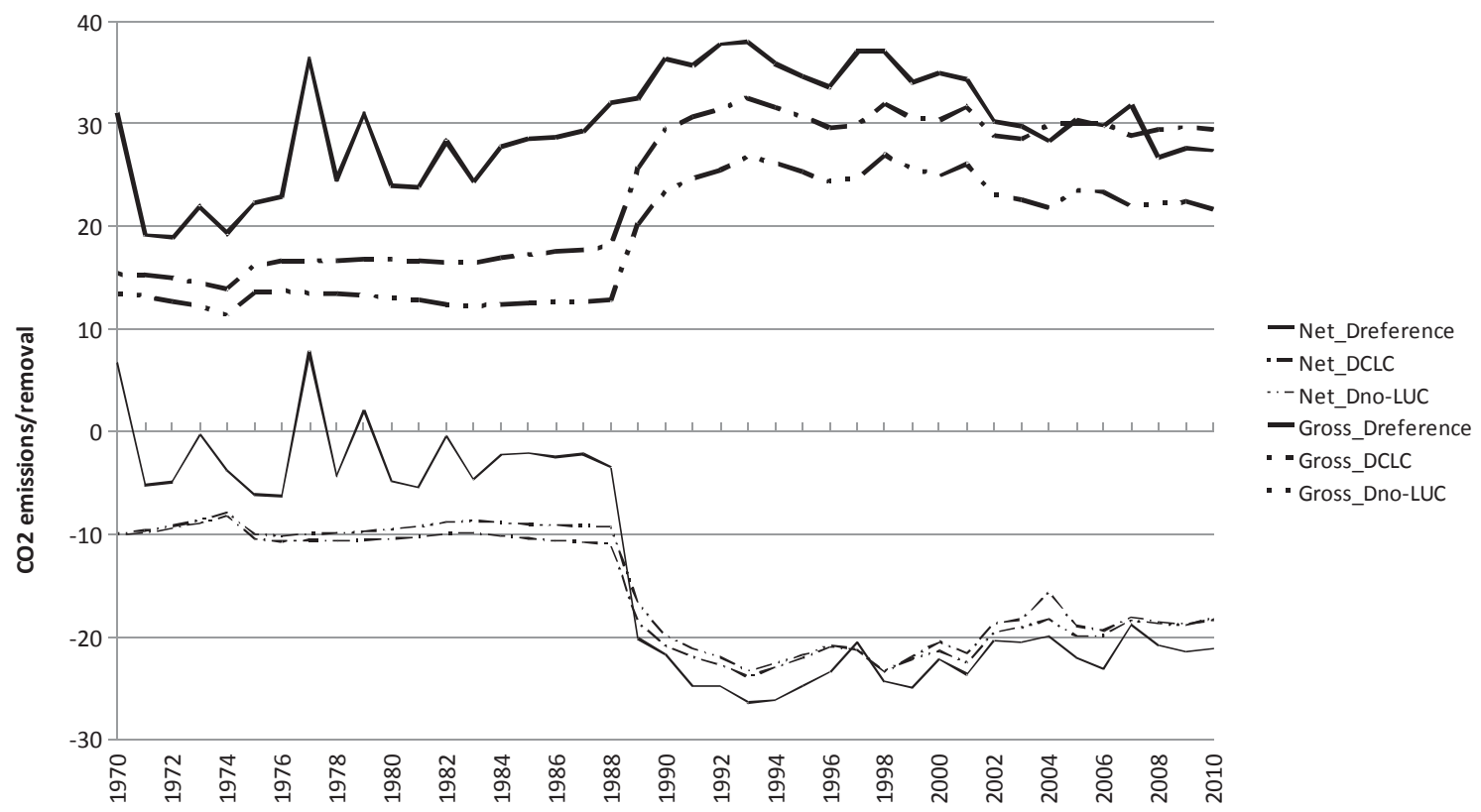

Figure 1 Annual gross and net $\mathrm{CO}_{2}$ inventory estimates according to various land datasets

estimates. The general pattern of the reference dataset maintained, since no better data was available to modify the inputs with strong general effect (e.g. peaks of permanent woody crops - vineyards and orchards). The order of magnitude of emissions/removals was not significantly different amongst datasets. Under any of the modified datasets, net and gross estimates were generally larger for land remaining in the same category and smaller for lands under conversions, compared to reference (Table 5).

Overall, for modified datasets net LULUCF estimates were larger because of larger sinks estimated for all major land uses. Noteworthy, $\mathrm{MD}_{\text {combined }}$ dataset, which can be assumed as the most realistic land dynamic structure (capturing both hayfield conversion to woodland

Table 5 Deviation from reference based estimates of total net and gross $\mathrm{CO}_{2}$ fluxes over 1970-2010 on land subcategories

\begin{tabular}{|c|c|c|c|c|c|c|c|c|c|c|}
\hline \multirow[b]{2}{*}{$\begin{array}{l}\text { Land } \\
\text { subcategory }\end{array}$} & \multicolumn{5}{|c|}{ Gross estimate } & \multicolumn{5}{|c|}{ Net estimate } \\
\hline & $\begin{array}{l}\mathrm{MD}_{\text {non- }} \\
\operatorname{LUC}(\%)\end{array}$ & $\mathrm{MD}_{\mathrm{CLC}}$ & $\begin{array}{l}\mathrm{MD}_{\text {hayfield }} \\
(\%)\end{array}$ & $\begin{array}{l}\mathrm{MD}_{\text {arable }} \\
(\%)\end{array}$ & $\begin{array}{l}\mathrm{MD}_{\text {combined }} \\
\text { (\%) }\end{array}$ & $\begin{array}{l}\mathrm{MD}_{\text {non- }} \\
\text { LUC (\%) }\end{array}$ & $\begin{array}{l}\mathrm{MD}_{\mathrm{CLC}} \\
(\%)\end{array}$ & $\begin{array}{l}\mathrm{MD}_{\text {hayfield }} \\
(\%)\end{array}$ & $\begin{array}{l}\mathrm{MD}_{\text {arable }} \\
(\%)\end{array}$ & $\begin{array}{l}\mathrm{MD}_{\text {combined }} \\
(\%)\end{array}$ \\
\hline $5 \mathrm{~A} 1$ & 5 & 11 & 2 & 0 & -1 & 5 & 11 & 2 & 0 & -1 \\
\hline $5 \mathrm{~B} 1$ & 0 & 0 & 0 & -8 & -3 & 127 & 122 & -1 & -30 & -16 \\
\hline $5 \mathrm{C} 1$ & 4 & 14 & 9 & 23 & 3 & 4 & 14 & 9 & 23 & 3 \\
\hline $5 \mathrm{~A} 2$ & 16 & 14 & 0 & 0 & 0 & 16 & 14 & 0 & 0 & 0 \\
\hline $5 B 2$ & $n a$ & -66 & -6 & 0 & 36 & na & -66 & -6 & 0 & 37 \\
\hline $5 C 2$ & na & -84 & 0 & -4 & -39 & na & -83 & -3 & -9 & -52 \\
\hline $5 D 2$ & na & -76 & -17 & 3 & -20 & na & -71 & -44 & 9 & -59 \\
\hline $5 E 2$ & na & -100 & -3 & 3 & 1 & $n a$ & -100 & -9 & -6 & -18 \\
\hline $5 F 2$ & na & -64 & -2 & 0 & -5 & $n a$ & -64 & -2 & 0 & -5 \\
\hline Total & $n a$ & -65 & -11 & -3 & 15 & $n a$ & -64 & -10 & -3 & 15 \\
\hline & -28 & -20 & -1 & 4 & 0 & 16 & 19 & 5 & 16 & 2 \\
\hline
\end{tabular}

Note. Rows in italics denote sources, the others are sinks. Negative signs mean smaller $\mathrm{CO}_{2}$ removals or emissions estimates compared to value estimated by reference dataset. 
and conversion of arable to pasture over last decades) has shown negligible effect for both gross $(+2 \%)$ and net estimates $(+0 \%)$ compared to reference. Assuming no woodlands by $\mathrm{MD}_{\text {hayfield }}$ resulted in $+5 \%$ higher total net estimates because of much smaller emissions when hayfields were needed for conversions to other uses. The scenario associated to dataset involving less arable land $\left(\mathrm{MD}_{\text {arable }}\right)$ also resulted in larger gross and net estimates due to availability of arable land to satisfy the need for conversions to higher $\mathrm{C}$ stocks land categories.

Datasets affect significantly the estimates of the main contributor to land $\mathrm{CO}_{2}$ inventory, the forestland sink. Generally across the datasets, both remaining forest and conversions to forest were larger sinks compared to reference, e.g. CLC estimates $+11 \%$ and $\mathrm{MD}_{\text {non-LUC }}$ estimates $+5 \%$ larger forest sink than reference. Estimation showed strong annual variability caused by annual harvest change in post- compared to pre-1990.

All modified datasets resulted in nonnegligible inventory contribution of conversions compared to the reference. In average, according to reference dataset, conversions contributed by $7 \%$ in net and $28 \%$ in gross CO2 inventory estimate. $\mathrm{D}_{\mathrm{CLC}}$ resulted in largest effect caused by land conversions, i.e. $+14 \%$ larger sink for conversions to forestland compared to reference dataset. Regarding deforestation, $\mathrm{D}_{\mathrm{CLC}}$ heavily underestimated emissions from deforestation for pre-1990, but not for post-1990. Other conversions turned to relatively smaller or larger emissions whenever woodlands and grassland were converted to any other land. The emissions from conversions to cropland have decreased compared to the reference because of less conversions occurring in wetlands converted to arable (i.e. as under $\left.\mathrm{MD}_{\text {arable }}\right)$.

\section{Contribution of the change in $\mathrm{C}$ pools}

$\mathrm{CO}_{2}$ land inventory was dominated by the change in the living biomass. On average, it represented $83 \%$ of LULUCF's gross flux, ranging from $100 \%$ on forestland and wetlands to $37 \%$ in conversions to settlements, depending on how, and if, change in soils organic matter was considered in calculations. Annual flux varied widely in time especially under sudden land use change affecting living biomass in conversions from high to low Cstock lands (e.g. pasture conversion to arable), which can also explain often inter-annual variability. On other hand, the flux resulting from changes of litter, dead wood and soil organic matter pools, taken together, represented in average $17 \%$ of gross estimate. Actually, soil pool related emissions were more relevant for non-forest subcategories and for any land conversions.

\section{Uncertainty and sensitivity analysis of the reference dataset}

Attaching a stochastic process to the reference dataset resulted in $31 \%$ uncertainty of the annual $\mathrm{CO}_{2}$ net removals for year 2010, slightly higher than $27 \%$ for the corresponding gross estimate. The lowest relative uncertainty was obtained for the net estimate related to forest land: $21 \%$ for 'remaining' and $10 \%$ for 'conversions to forest'. The relative uncertainty for $\mathrm{CO}_{2}$ removals or emissions from non-forest land categories was more than $50 \%$ for stable lands and more than $100 \%$ for conversions. Attaching further uncertainty to 'conversions allocation factors' also resulted in some 10 percentage points larger uncertainty for all conversions related estimate (although complex correlations among them were not accounted by our model). With $\mathrm{D}_{\mathrm{CLC}}$, the uncertainty reached $55 \%$ for total net LULUCF and $40 \%$ for forestland.

Further on, the sensitivity analysis showed that the area of "woodlands" plays a very significant role in defining the uncertainty of estimates of both forest sink and total LULUCF estimates. Also, LULUCF estimate were more 
affected by the uncertainty of the change in $\mathrm{C}$ pools than land area.

\section{Discussion}

The right question to ask when an environmental commitment related to land has to be made is whether the data qualitatively, quantitatively and temporally allow reporting according to the requirements, or at least how available data can be combined or improved to serve that purpose. This involves an exercise of screening of all available datasets available in the country.

Intense land reorganization occurred in Romania in pre-1990 because of land confiscation and industrialization and socio-economic transition in post-1990. Overall, across Eastern Europe underlying political shift has generated a change in land use system affecting one sixth of the planet's land surface (Hostert et al., 2011). Local and regional impacts on cultural landscape and biodiversity are expected major as well (Taff et al., 2010; Kuemmerle et. al, 2011). Under such complex socio-economic environment, consistency within land use statistics may be challenged because of inertial practices related to data collection and processing, and also due to recent major changes in statistical systems (i.e. towards EU harmonization). The risk for lower quality of the national land statistics increased in post-1990, because of institutional and land structural changes, actually occurring in all East European countries, cited for Hungary (Laczka and Soós, 2003; Government of Hungary, 2012), Bulgaria (Government of Bulgaria, 2012), Estonia (Government of Estonia, 2012), Poland (Government of Poland, 2012) and Slovenia (Petek, 2008). As a consequence statistical reports are likely not updated, generating mismatches between recorded and actual land use, and time series affected by occasional true-ups sometimes only for some land sub-categories or activities. For Romania, additional to all these, the fact that underlying database of reference dataset is not spatially explicit, raises doubt on our result of little land use change over 1970-2010. For example reference dataset (INSSE, 2010) shows a shift across all land categories from 1987 to 1988 as a consequence of a post-1990 retroactive clear up. Also, outliers noticed for "orchards" and "woodland" in 1988-1989 and over 1998-2004 were most likely caused by external factors like political pressure to report more forestland (without any factual modification of the concerned area) or because of methodological inertia or financial/ institutional difficulties in updating changes. Interestingly, the change of forest definition, first set in 1962 (Law 3/1962) changed in 1996 (Law 26/1996), 2005 (Government Ordinance 95/2005) and 2008 (Law 46/2008) did not result in any significant variation of forest area reported by reference dataset. Relevant for GHG inventory is also the fact that reference dataset seemed much less able to provide detailed data on actual spatial composition of landscape microstructure (Lipsky, 2010), further complicated because of high land abandonment when pattern variation within landscape can be greater than among landscape (Dendoncker et al., 2008). From this perspective, $D_{C L C}$ may actually provide a more realistic area of forests and grassland under a "land cover" definition, and notable, it estimates, for both, some $10 \%$ more areas than reported by the national statistics. More forest is also confirmed by $1^{\text {st }}$ NFI cycle which rigorously implements thresholds based forest definition (http://roifn.ro/site/). The reference dataset implements a strict "land use" definition with forestland composed from 'national forest fund, so called NFF' and 'forest vegetation outside national forest fund' (or woodlands). NFF represents $95 \%$ of country's forest accurately mapped as being subject to forest management planning and administration. Woodlands, which resulted by the spontaneous forest expansion, have not been subject of forest management planning, so related information is extremely poor; such lands are likely reported by national statistics inconsistently in time either as woodland or pasture, while recorded as forest vegetation under any 
'land cover' assessment (i.e. National Forest Inventory - NFI or remote sensing mapping in scientific papers or CLC). Overall, this looks like an underestimation of forest area as long as land cover can be used as an adequate proxy for forestland area, instead of land use one. In any case, the main advantage in using national statistics lays in its apparent full time consistency and complete country coverage, thus not requesting a challenging harmonization of different data sources (Woodbury et al., 2007).

The reference dataset is actually a combination of heterogeneous underlying sources offering indirect guarantee for complete and consistent land use capturing in time and space. Land registry is a major source of data, usually locally implemented cadastral database as ownership information, complemented by operational data in forestry, both backed by ground measurements. Additional information is provided by sectorial statistics in agriculture mostly based on municipality or owners/farmers' declarations. Notably, for the agricultural lands reported under agricultural statistics, errors can be particularly high when "activity area" is taken as a proxy for "land use", or when subjective methods are involved (e.g. non-rigorous implementation of land definition on owner declaration) or lack of rigorous checks and quality assurance/control procedures. Using such data for emissions reduction commitments on land is further strongly limited by non-spatially explicit nature of information and impossibility to be processed as a unique national database. Arguably, land under national forest fund and its conversions are part of a slightly better defined survey system, still technologically obsolete and dominated by bureaucratic and subjective data manipulation instead of a modern geo-referenced digital database. The most significant weakness of reference dataset related to forest land is that it implements an exclusive forest definition, which is 'land administration oriented' thus focusing on national forest fund, instead of one based on quantitative thresholds which would be able to capture all forests and change no matter of their cadastral status.

Current GHG inventory methods involve land area in a multiplicative operation, thus any dataset inconsistency has a quantitative consequence on $\mathrm{CO}_{2}$ inventory accuracy and uncertainty. Under current forestry planning approach, the reference dataset should provide unbiased annual estimates of land area for national forest land and its conversions (completely based on ground measurements), although deforestation data is not publicly transparent. The lowest confidence is attached to estimate related to woodlands area, which are erratically reported either as woodlands or hayfields and can be only classified as stable forestland after development of a management plan. Compared to reference dataset, $\mathrm{D}_{\mathrm{CLC}}$ underestimates by 34 $\%$ annual areas of conversions to/from forestland, especially conversions from forests in pre-1990. While it provides convenient countrywide and spatially explicit data also for 1990 , reliability of $\mathrm{D}_{\mathrm{CLC}}$ remains low because of relatively coarse scale mapping less appropriate for measuring conversions. Uncertainty of CLC area estimates was never derived and any agreement of areas to other datasets at aggregated level are assumed to occur by chance (Gallego and Bamps, 2008, Hazeu and de Wit, 2004; Cruickshank and Tomlinson, 1996). Since the strongest non-land influence on the GHG inventory is hold by the changes in living biomass pool from forestland and organic matter soil pool for lands under conversions, using CLC dataset would introduce the risk of overestimation of annual sink because of larger forest area without adjusting accordingly the wood harvest. Although sensitivity analysis did not show harvest as an important input, it remains an issue for Romanian LULUCF inventory to be checked and confirmed by independent sources (e.g. from second cycle of the NFI), since national statistics reports a halving of annual wood har- 
vest in post-1990 compared to pre-1990, thus national statistics coverage of all wood harvest is questionable. Overall, structure of LULUCF estimate is similar to other national GHG inventory estimates, e.g. in Germany's inventory living biomass pool change is responsible for $76 \%$, dead wood $15 \%$, litter $5 \%$ and soil $4 \%$ of their net annual removals (UBA, 2012).

Datasets introducing partial modifications only affect forestland and show negligible changes of overall inventory estimates compared to reference dataset. Non-annual land assessments introduce smoothness of time series between start-end moments, e.g. $\mathrm{D}_{\mathrm{CLC}}$ annualizes the short term effects of major sudden changes. Because of different concepts behind land assessment and definitions implemented by various datasets, datasets modifying information used here would serve better for verification purpose than for adjusting the reference data, while triggering national discussion on the need to improve the consistency of land data.

Emissions and removals from land conversions have rather small contributions to inventory in Romania. Areas in conversions represent a very small share in any land category, smaller for forest $(<4 \%)$ and larger for cropland and grassland $(<8 \%)$, unlike in other countries economically more developed, e.g. France and the UK report by $30 \%$ of cropland area as being in cropland-grassland conversion (CITEPA 2012, Brown et al. 2012). Globally, land conversions are a major source of emissions, i.e. in the EU's member states there were some 28 mil. ha of land under conversions in 2010 , of which $6 \%$ were conversions from forestland and $22 \%$ to forestland, $80 \%$ were conversions from grassland and cropland together, which corresponded to $3 \%$ of the net and $14 \%$ of the gross annual GHG inventory estimates (Mandl et al. 2012). Land use pattern and trends are somehow similar across Europe, with expanding of settlements and forests over the last 20 years mainly on grassland and cropland as dominant trend (Rounsevell \&
Reay, 2009, EEA 2013) indicating an increasingly diffuse urbanization process and continuing landscape fragmentation (EEA 2006). In any case, current ability of land assessment system to capture land use changes is very limited, as long as LUM implements the rule that area in certain conversion equals the difference between net areas at the end of consecutive years. This mostly affects estimates for nonforest land conversions, since LUM ensures that the area of conversions to/from forest is fully accounted annually as reported by operational forestry.

Uncertainty of inventory annual estimate is dominated by forest sink, and apparently influenced by uncertainties of $\mathrm{C}$ pool changes. Our sensitivity analysis did not reveal uncertainty of land areas as a significant input, nor for stable land uses and for conversions. Generally, the uncertainty is known as larger for areas of conversions and smaller for stable land use (Canadell et al. 2007). In Romania, the area of national forest fund and conversions to/from national forest fund are accurately recorded by ground measurements, but large uncertainties remain for areas and emissions/removals estimated for conversions of woodlands, grassland and wetlands to/from cropland, as well as on regrowth of cut forests (e.g. private owned forests are reportedly subject of degradation). According to the error propagation method applied, the contributions of highly uncertain $\mathrm{CO}_{2}$ emissions and removals estimates associated to non-forest lands have very small contribution to LULUCF inventory under the dominance of less uncertain forest sink. On the other hand, although the annual $\mathrm{C}$ stock change factors in all pools are taken as certain values in this study, their often large uncertainty was often highlighted, especially for soils of any land use (Bellamy et al. 2005, Dinca et al. 2012) under the long-term effect of historical changes and difficulty in attributing them to recent changes (Kirk \& Bellamy 2010). Noteworthy, assuming linear dynamic of $\mathrm{C}$ loss from soils is contrary 
to evidences showing a nonlinear and asymmetric change of the $\mathrm{C}$ stock in relation to reverse land use conversions (e.g. Ragot and Schubert 2008), but approach is accepted for the sake of GHG inventory reporting comparability. Following the UNFCCC requirement that uncertainty analysis should be a mean to improve GHG inventories (so not an indicator of inventory's accuracy), deep concern remains for forest land data provided by reference dataset. Nevertheless, the sink currently reported by GHG inventory based on reference data can be assumed as most conservative (in the sense that forest sink is not overestimated; UNFCCC 2011, Grassi et al. 2008). Romania's latest official submission to UNFCCC estimated average annual $\mathrm{CO} 2$ removals between 1719 Tg CO2 over 1990-2010 (Government of Romania, 2012), while independent research estimated higher annual forestland sink of some $50 \mathrm{Tg} \mathrm{CO} 2$ for the same period (Olofsson et al. 2009, Olofsson et al. 2011) based on a forest area very close to the results of $1^{\text {st }} \mathrm{NFI}$ (IFN, 2014). Compared to pre-1990, when annual sink was rather low, land abandonment and management extensivization in post-1990 have led to increases of $\mathrm{C}$ stock in all pools, which again supports conservative estimates by current version of national GHG inventory.

\section{Conclusions}

Because of the long-term nature of the changes in C pools, time consistency of land data, especially on conversions, is crucial for an accurate inventory of $\mathrm{CO}_{2}$ emissions and removals on lands. Among several alternative land datasets tested for Romania, the reference dataset prepared from the national statistics, allows reporting a conservative LULUCF estimate in the national GHG inventory for the entire time series. Nevertheless, one should notice that reference data is qualitatively heterogeneous: national forest fund area and its conversions are accurate as updated and based on ground measurements, unlike non-forest lands and their conversions. Underestimation of emissions from deforestation and uncertainty of the GHG inventory estimates calculated here discourages using remote sensing based $\mathrm{D}_{\mathrm{CLC}}$, especially because of underestimation of areas under conversions from forests, overestimation of forest sink by larger forest areas and unavailability of better harvest data. In fact this is valid when all other datasets are tested; the largest greenhouse effect is related to emissions and removals from conversions and wood harvesting level (pre-and post-1990 inventories, as well as likely partial coverage of true harvesting). Additional available data from sectoral statistics on various conversions do not improve the inventory estimate but can be rather helpful for verification purpose.

Apparently, the uncertainty of national inventory depends more on changes in $\mathrm{C}$ pools than on land data.

Meeting reporting requirements of commitments on climate change, emissions reduction accounting and adaptation actions accurate LULUCF estimates has to be achieved by combining all spatially explicit resources available around NFI grid, in line with most modern systems of land use assessments.

\section{Acknowledgements}

VNBB acknowledges funding from contract 88/2014 the Ministry of Environment and Climate Change. GM and MS acknowledge funding from project GHG Europe FP7-ENV2009-1-244122. We thank to the paper reviewers for their effort.

\section{References}

Bellamy P.H., Loveland P.J., Bradley R.I., Lark R.M. and Kirk G.J.D., 2005. Carbon losses from all soils across England and Wales 1978-2003. Nature 437: 245-248. DOI: 10.1038 /nature04038.

Brown K., Cardenas L., MacCarthy J., Murrells T., Pang Y., Passant N., Thistlethwaite G., Thomson A., Webb 
N., et al., 2012. UK Greenhouse Gas Inventory 1990 to 2010. Annual Report for Submission under the Framework Convention on Climate Change 2012. Web: http:// unfccc.int/national_reports/annex_i_ghg_inventories/ national_inventories_submissions/items/6598.php. Accessed 14/06/2012.

Büttner G., Feranec J., Jaffrain G., 2002. Corine land cover update 2000 - Technical guidelines. Technical report. Joint Reasearch center and European Environment Agency.

Canadell J.G., Le Quéré C., Raupach M.R., Field C.B., Buitenhuis E.T., Ciais P., Conway T.J., Gillett N.P., Houghton R.A., Marland G., 2007. Contributions to accelerating atmospheric $\mathrm{CO} 2$ growth from economic activity, carbon intensity, and efficiency of natural sinks. PNAS 104(47): 18866-18870.

Caetano M., Nunes V., Nunes A., 2009. CORINE Land Cover 2006 for Continental Portugal. Technical Report, Instituto Geografico Portugues. Web: http://www. igeo.pt/gdr/pdf/CLC2006_final_report.pdf. Accessed 14/06/2012.

CITEPA, 2012. Rapport national d'inventaire pour la France au titre de la Convention Cadre des Nations Unies sur les Changements Climatiques et du Protocole de Kyoto - édition de mars 2012. Centre Interprofessionnel Technique d'Etudes de la Pollution Atmosphérique. Web: http://unfccc.int/national reports/annex i ghg inventories/national_inventories_submissions/items/6598. php. Accessed 14/06/2012.

Cruickshank M.M., Tomlinson R.W., 1996. Application of CORINE Land Cover methodology to the U.K.- some issues raised from Northern Ireland. Global Ecology and Biogeography Letters 5 (4/5) Remote Sensing and GIS in the Service of Ecology and Biogeography: A Series of Case Studies.

Dendoncker N., Schmit C., Rounsevell M., 2008. Exploring spatial data uncertainties in land-use change scenarios. International Journal of Geographical Information Science 22(9): 1013-1030. DOI: 10.1080/1365881070 1812836

Dincă L.C., Spârchez G., Dincă M., Blujdea V.N.B., 2012. Organic carbon concentrations and stocks in Romanian mineral forest soils. Annals of Forest Research 55(2): 229-241.

European Environmental Agency (EEA), 2006. Corine land cover database passes accuracy test. Web: http:// www.eea.europa.eu/highlights/Ann1151398593. Accessed 23.07.2013.

EEA, 2013. Annual European Union greenhouse gas inventory 1990-2010 and inventory report 2012. European Environmental Agency. Technical report no 8. Web: http://www.eea.europa.eu/publications/european-union-greenhouse-gas-inventory-2013. Accessed 16.07.2013.

Exnerova Z., Cienciala E., 2009. Greenhouse gas inventory of agriculture in the Czech Republic. Plant Soil and Environment 55(8): 311-319.

Federal Environment Agency (UBA) of Germany, 2012.
National Inventory Report for the German Greenhouse Gas Inventory 1990 - 2010. Submission to the United Nations Framework Convention on Climate Change and the Kyoto Protocol 2012. Available at: http://unfccc. int/national_reports/annex_i_ghg_inventories/national_inventories_submissions/items/6598.php. Accessed $14 / 06 / 2012$.

Foley J.A., DeFries R., Asner G.P., Barford C., Bonan G., Carpenter S.R., Chapin F.S., Coe M.T., Daily G.C., Gibbs H.K., Helkowski J.H., Holloway T., Howard E.A., Kucharik C.J., Monfreda C., Patz J.A., Prentice I.A., Ramankutty N., Snyder P.K., 2005. Global Consequences of Land Use. Science 309(5734): 570-574. DOI: $10.1126 /$ science.1111772.

Gallego J, Bamps C., 2008. Using CORINE land cover and the point survey LUCAS for area estimation. International Journal of Applied Earth Observation and Geoinformation 10: 467-475. DOI: 10.1016/j.jag.2007.11.001.

Giurgiu, V., Draghiciu D., 2004. Modele matematicoauxologice si tabele de productie pentru arborete. Editura Ceres, $607 \mathrm{p}$.

Goulet E., Morlat R., 2011. The use of surveys among wine growers in vineyards of the middle - Loire Valley (France), in relation to terroir studies. Land Use Policy 28(4): 770-782. DOI: 10.1016/j.landusepol.2011.01.00 3.

Government of Bulgaria, 2012. National inventory report 2012 for Greenhouse Gas Emissions Submission under the UNFCCC and the Kyoto Protocol. Web: http://unfccc.int/national reports/annex i ghg inventories/national_inventories_submissions/items/6598.php. Accesed 10.2014.

Government of Estonia, 2012. Greenhouse gas emissions in Estonia 1990-2010. National inventory report under the UNFCCC and the Kyoto Protocol. Submission to the UNFCCC secretariat. Web: http://unfccc.int/national reports/annex $\mathrm{i}$ ghg inventories/national inventories_submissions/ items/6598.php. Accesed 10.2014.

Government of Hungary, 2012. National Inventory Report for 1985-2010 Hungary. Submission to UNFCCC. Web: http://unfecc.int/national_reports/annex_i_ghg_inventories/national_inventories_submissions/items/6598. php. Accesed 10.2014.

Government of Poland, 2012. Poland's national inventory report 2012. Greenhouse Gas Inventory for 1988-2010. Submission under the UN Framework Convention on Climate Change and its Kyoto Protocol. Web: http:// unfccc.int/national_reports/annex_i_ghg_inventories/ national_inventories_submissions/items/6598.php. Accesed 10.2014 .

Government of Romania, 2012. Romania's Greenhouse Gas Inventory 1989-2010. National Inventory Report. Web: http://unfecc.int/national reports/annex i ghg inventories/national_inventories_submissions/items/6598. php. Accesed 10.2014.

Government of Romania, 2014. National Greenhouse Gas Inventory and Inventory Report of Romania. Web: http://unfccc.int/national_reports/annex_i_ghg_inven- 
tories/national_inventories_submissions/items/8108. php. Accesed 10.2014.

Grassi G., Monni S., Federici S., Achard F., Mollicone D., 2008. Applying the conservativeness principle to REDD to deal with the uncertainties of the estimates. Environemental Research Letters 3, 035005. DOI: 10.1088/17489326/3/3/035005.

Hazeu G.W., De Wit A.J.W., 2004. CORINE land cover database of the Netherlands: monitoring land cover changes between 1986 and 2000. EARSeL eProceedings 3(3).

Hostert P., Kuemmerle T., Prishchepov A., Sieber A., Lambin E.F., Radeloff V.C., 2011. Rapid land use change after socio-economic disturbances: the collapse of the Soviet Union versus Chernobyl. Environmental Research Letters 6(4): 045201. DOI: 10.1088/17489326/6/4/045201.

Houghton R.A., Hackler J. L., 2001. ORNL/CDIAC-131, NDP-050/R1 (Oak Ridge National Laboratory, Oak Ridge, TN, 2001).

INSSE, 2010. Anuarul statistic 2010 -Serii de timp 19902009. Web: http://www.insse.ro/cms/rw/pages/index. ro.do. Accesed 10.2014.

Ioras F., Abrudan I.V., 2006. Romanian forestry sector - privatisation facts. International Forestry Review. 8(3): 361-367. DOI: 10.1505/ifor.8.3.361.

Intergovernmental Panel on Climate Change (IPCC), 2004. Good practice guidance for land use, land- use change and forestry. In: Penman J., Gytarsky M., Hiraishi T., Kruger D., Pipatti R., Buendia L., Miwa K., Ngara T., Tanabe K., Wagner F. (eds)., IPCC/OECD/IEA/IGES. Hayama, Japan. ISBN 4-88788-003-0

Intergovernmental Panel on Climate Change (IPCC), 2006. Guidelines for national greenhouse gas inventories. In: Eggelstone, S., L. Buemdia, K. Miwa, T. Ngara and K. Tanabe (eds.). IPCC/OECD/IEA/IGES. Hayama, Japan.

Kirk G.J.D, Bellamy P.H., 2010. Analysis of changes in organic carbon in mineral soils across England and Wales using a simple single-pool model. European Journal of Soil Science 61(3): 406-411. DOI: $10.1111 / \mathrm{j} .1365$ 2389.2010.01242.x.

Kuemmerle T., Olofsson P., Chaskovsky O., Baumann M., Ostapowicz K., Woodcock C.E., Houghton R.A., Hostert P., Keeton W.S., Radeloff V.C., 2011. Post-Soviet farmland abandonment, forest recovery, and carbon sequestration in western Ukraine. Global Change Biology 17(3): 1335-1349. DOI: 10.1111/j.13652486.2010.02333.x.

Laczka É., Soós L., 2003. Some Characteristics of the Hungarian Agriculture in the 1990s. Hungarian Statistical Review, Special issue 8, 3-19. Web: http://www.ksh. hu/statszemle_archive/2003/2003_K8/2003_K8_003. pdf. Accesed 10.2014.

Lewis J.I., 2010. The Evolving Role of Carbon Finance in Promoting Renewable Energy Development in China. Energy Policy 38(6): 2875-2886. DOI: 10.1016/ j.enpol.2010.01.020.
Le Quéré C., Andres R.J., Boden T., Conway T., Houghton R.A., House J.I., Marland G., Peters G.P., van der Werf G., Ahlström A., Andrew R.M., Bopp L., Canadell, J.G., Ciais P., Doney S.C., Enright C., Friedlingstein P., Huntingford C., Jain A.K., Jourdain C., Kato E., Keeling R.F., Klein Goldewijk K., Levis S., Levy P., Lomas M., Poulter B., Raupach M.R., Schwinger J., Sitch S., Stocker B.D., Viovy N., Zaehle S., Zeng N., 2012. The global carbon budget 1959-2011, Earth Syst. Sci. Data Discuss., 5: 1107-1157. DOI: 10.5194/essdd-5-11072012.

Lipsky Z., 2010. The changing face of the Czech rural landscape. Landscape and Urban Planning 31(1-3): 3945.

Mandl N., Blujdea V., Gager M., Goll M., Grassi G., Gugele B., Harthan R., Herold A., Jobstmann H., Koether T., Leip A., Mellios G., Pendolovska V., Perl D., Pinterits M., Poupa S., Ritter M., Scheffler M., Stranner G., Szemsova J. and Velghe R., 2012. Annual European Community greenhouse gas inventory 1990-2008 and inventory report 2010 Submission to the UNFCCC Secretariat. Technical report No 03/2012, European Environment Agency. Web: http://www.eea.europa. eu/publications/european-union-greenhouse-gas-inventory-2012. Accesed 10.2014.

Inventarul Forestier National (IFN), 2014. Rezultate IFN - ciclul 1. Web: http://roifn.ro/site/rezultate-ifn-1/. Accessed 18.11.2014.

Olofsson P., Woodcock C., Baccini A., Houghton R.A., Ozdogan M., Gancz V., Blujdea V., Torchinava P., Tufekcioglu A. and Baskent E.Z., 2009. The effects of land use change on terrestrial carbon dynamics in the Black Sea region. In: Pavel Ya. Groisman, Sergiy V. Ivanov (eds.) Regional aspects of climate-terrestrial-hydrologic interactions in non-boreal Eastern Europe Series: NATO Science for Peace and Security Series C: Environmental Security, pp 175-182. DOI: 10.1007/978-90-481-22837 19.

Olofsson P., Kuemmerle T., Griffiths P., Knorn J., Baccini A., Gancz V., Blujdea V., Houghton R.A., Abrudan I.V. and Woodcock C.E., 2011. Carbon implications of forest restitution in post-socialist Romania. Environmental Research Letters 6(2011) 045202. DOI: 10.1088/17489326/6/4/045202.

Ostle N.J., Levy P.E., Evans C.D., Smith P., 2009. Review UK land use and soil carbon sequestration. Land Use Policy 26S, S274-S283. DOI: 10.1016/j.landusepol.20 09.08.006.

Petek F., 2008. Land use in Slovenia. Web: http://www.theslovenian.com/articles/2008/petek.pdf. Accesed 10.2014.

Ragot L., Schubert K., 2008. The optimal carbon sequestration in agricultural soils: Do the combineds of the physical process matter? Journal of Economic Combineds \& Control 32: 3847- 3865. DOI: 10.1016/ j.jedc.2008.03.007.

Reich P.B., 2011. Taking stock of forest carbon. Nature Climate Change (1) 346-347.

Rounsevell M.D.A., Reay, D.S., 2009. Land use and climate 
change in the UK. Land Use Policy 26S, S160-S169. DOI: 10.1016/j.landusepol.2009.09.007.

Stinson G., Kurz W.A., Smyth C.E. et al., 2011. An inventory-based analysis of Canada's managed forest carbon combineds 1990 to 2008. Global Change Biology 17: 2227-2244. DOI: 10.1111/j.1365-2486.2010.02369.x.

Taff G.N., Müller D., Kuemmerle T., Ozdeneral E., Walsh S.J., 2010. Reforestation in Central and Eastern Europe after the Breakdown of Socialism. In Nagendra, Harini, Southworth, Jane, Tress, Bärbel \& Tress, Gunther (eds.), Reforesting Landscapes: Linking Pattern and Process (pp. 121-47). Dordrecht, The Netherlands: Springer.

UNFCCC, 2005. Decision 16/CMP.1 Land use, land-use change and forestry. FCCC/KP/CMP/2005/8/Add.3.

UNFCCC, 2011. Decision 15/CP.17 Revision of the UN-
FCCC reporting guidelines on annual inventories for Parties included in Annex I to the Convention. FCCC/ CP/2011/9/Add.2.

USDA, 2008. U.S. Agriculture and Forestry Greenhouse Gas Inventory: 1990-2005. Agriculture 2600(8): 161.

Van der Krabben E., Jacobs H.M., 2013. Public land development as a strategic tool for redevelopment: Reflections on the Dutch experience. Land Use Policy (30)1: 774-783. DOI: 10.1016/j.landusepol.2012.06.002.

Woodbury P.B., Heath L.S., Smith J.E., 2007. Effects of land use change on soil carbon cycling in the conterminous United States from 1900 to 2050, Global Biogeochemical. Cycles 21: GB3006, DOI: 10.1029/2007GB002950. 